http://ejournal.undip.ac.id/index.php/kapal

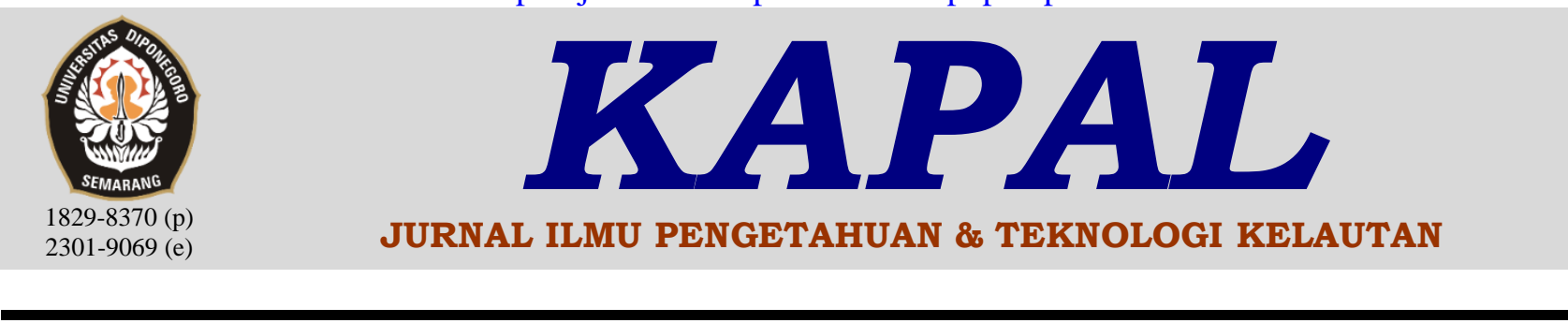

\title{
Analisa Kekuatan Deck BARGE NANIA 10070 DWT Dengan Dua Metode Pembebanan
}

\author{
Luh Putri Adnyani ${ }^{\left.()^{*}\right)}$, Nur Aisyah ${ }^{2)}$, Sulistijono ${ }^{3)}$, Rima Gusriana Harahap ${ }^{l)}$, Anggoronadhi Dianiswara ${ }^{l)}$, \\ Nurmawati ${ }^{1)}$ \\ 1)Program Studi Teknik Kelautan, Institut Teknologi Kalimantan \\ 2) Program Studi Teknik Perkapalan, Institut Teknologi Kalimantan \\ Kampus ITK Karang Joang, Balikpapan 76127 \\ ${ }^{3}$ Departemen Teknik Material \& Metalurgi, Institut Teknologi Sepuluh Nopember \\ Jl. Raya ITS, Sukolilo, Surabaya, Indonesia 60111
}

diajukan pada $: 21 / 02 / 19 \quad$ direvisi pada $: 11 / 06 / 19 \quad$ diterima pada $: 24 / 07 / 19$

\begin{abstract}
Abstrak
Kondisi struktur pelat tongkang dan banyak volume muatan, akan mempengaruhi jumlah tegangan yang mampu ditahan oleh suatu struktur. Analisa kekuatan deck dengan variasi pembebanan bertujuan untuk mengetahui tegangan maksimum yang berada di titik tertentu pada deck kapal, pada studi kasus ini adalah kapal tongkang Nania dengan adanya variasi metode pembebanan. Metode penelitian dimulai dengan pembebanan batu bara di atas tongkang dan membentuk gunungan yang jumlahnya bervariasi serta disusun secara memanjang kapal. Pemodelan elemen hingga hanya dilakukan pada daerah midship dengan ukuran model adalah panjang 18,28 meter, lebar 27,45 meter, dan tinggi 5,5 meter, yang disesuaikan dengan studi kasus di lapangan. Variasi pembenanan dilakukan untuk mendapatkan nilai tegangan maksimum, antara lain: variasi ke-1 adalah midship kapal dibebani 1 gunungan yaitu ketika tongkang membawa 4 gunungan batu bara keseluruhan sepanjang kapal, dengan tiap gunungan menyerupai prisma. Variasi ke-2 adalah 2 gunungan pada midship jika tongkang mengangkut 5 gunungan batu bara secara keseluruhan dengan bentuk gunungan adalah limas. Dengan menggunakan software elemen hingga didapatkan hasil tegangan maksimum berada pada area replating pada kedua variasi yang memiliki tegangan maksimum sebesar 394,39 MPa dan 369,97 MPa. Kedalaman deformasi dari kedua tipe pembebanan yaitu 27,783 mm dan 28,765 mm yang masih dibawah toleransi deformasi maksimum (36 mm). Nilai safety factor berdasarkan tegangan ultimate sertifikat material kapal Nania ialah 1,303 dan 1,389. Nilai rata-rata safety factor dari keseluruhan percobaan yaitu 1,346, diatas angka standar $S F=1$.
\end{abstract}

Copyright @ 2019, KAPAL, 1829-8370 (p), 2301-9069(e)

Kata Kunci : Tegangan, Struktur, Deformasi, elemen hingga, tongkang

\section{PENDAHULAN}

Dengan meningkatnya sektor industri batu bara, sangat diperlukan suatu alat transportasi yang dapat menunjang kegiatan pemuatan dan distribusi batu bara dan mampu mengangkut dalam jumlah yang besar. Batubara di transportasikan dari tempat tambang ke lokasi PLTD atau daerah lainnya yang menggunakan

*) Penulis Korespondensi :

Email : luhputria@itk.ac.id batubara [1]. Alat transportasi yang biasa digunakan adalah tongkang. Tongkang adalah alat apung yang tidak berawak dan tidak memiliki alat penggerak sendiri. Tongkang umumnya ditarik oleh tug boat untuk keperluan distribusi muatan [2].

Beberapa media ataupun laporan teknis melaporkan kenaikan kecelakaan kapal yang bukan hanya karena kesalahan manusia dan cuaca buruk, tetapi juga karena kegagalan struktur secara global [3]. Perhitungan analitical untuk kegagalan struktur tersebut sulit untuk dilakukan 
sehingga aplikasi metode elemen hingga perlu dilakukan.

Galangan di Indonesia mendapatkan pekerjaan reparasi tongkang dimana bagian midship tongkang patah akibat pembebanannya yang tidak merata dan juga karena pelat geladak yang telah menipis. Oleh karena itu, perlu dilakukan analisa terhadap konstruksi kapal terutama kontruksi pada geladak kapal yang dipengaruhi oleh pembebanannya. Karakteristik tongkang yang banyak terdapat di Indonesia adalah bagian atas terbuka, memiliki rasio panjang lebar dan rasio panjang tinggi yang tidak biasa dan beroperasi di perairan dangkal [3].

Penelitian ini menggunakan software bidang struktural yang merupakan perangkat lunak berbasiskan metode elemen hingga yang dipakai untuk menganalisa masalah-masalah rekayasa (engineering).

Beberapa jurnal hanya membahas tentang stabilitas dan kekuatan dari tongkang, salah satunya pada tongkang pengangkut limbah batu bara [4]. Pembahasan jurnal lainnya berfokus pada tegangan dan kekuatan struktur dengan pembebanan hidrodinamis [5] [6]. Tongkang diberikan pembebanan batu bara hanya dengan satu gunungan, namun lebih utama mengkaji stabilitas dan ekonomi [7].

Disamping Analisa mengenai stabilitas tongkang [8], kekuatan struktur tongkang sangat perlu diperhatikan. Apalagi mengingat banyaknya tongkang berumur yang berlayar di perairan Indonesia. Beberapa jurnal banyak membahas tentang kekuatan struktur yang berbasis elemen hingga [9] [10] [11] [12] [13] [14] [15] [16] [17] [18] [19].

Dari beberapa penelitian, masih belum ada pembahasan mengenai pembebanan batu bara yang membentuk gunungan prisma dan limas.

Tujuan dari penelitian ini adalah untuk mengetahui beban dan tegangan (stress) pada bagian deck ponton Nania ketika ada variasi gunungan batu bara saat transportasi dan mengamati kesesuaian antara hasil deformasi pelat dan hasil tegangan yang dimodelkan dibandingkan dengan sertifikat material.

\section{METODE}

Data sekunder diperoleh dari PT. Meranti Nusa Bahari yang sedang melakukan proses reparasi tongkang (barge) Nania. Data yang didapat meliputi: Rencana Umum Tongkang Nania, konstruksi profile, bukaan kulit dengan daerah yang direparasi, data pengecekan ketebalan, dan sertifikat material. Gambar 1 menunjukkan gambar bukaan kulit tongkang Nania yang sudah diarsir oleh pihak galangan disesuaikan dengan daerah replatting.

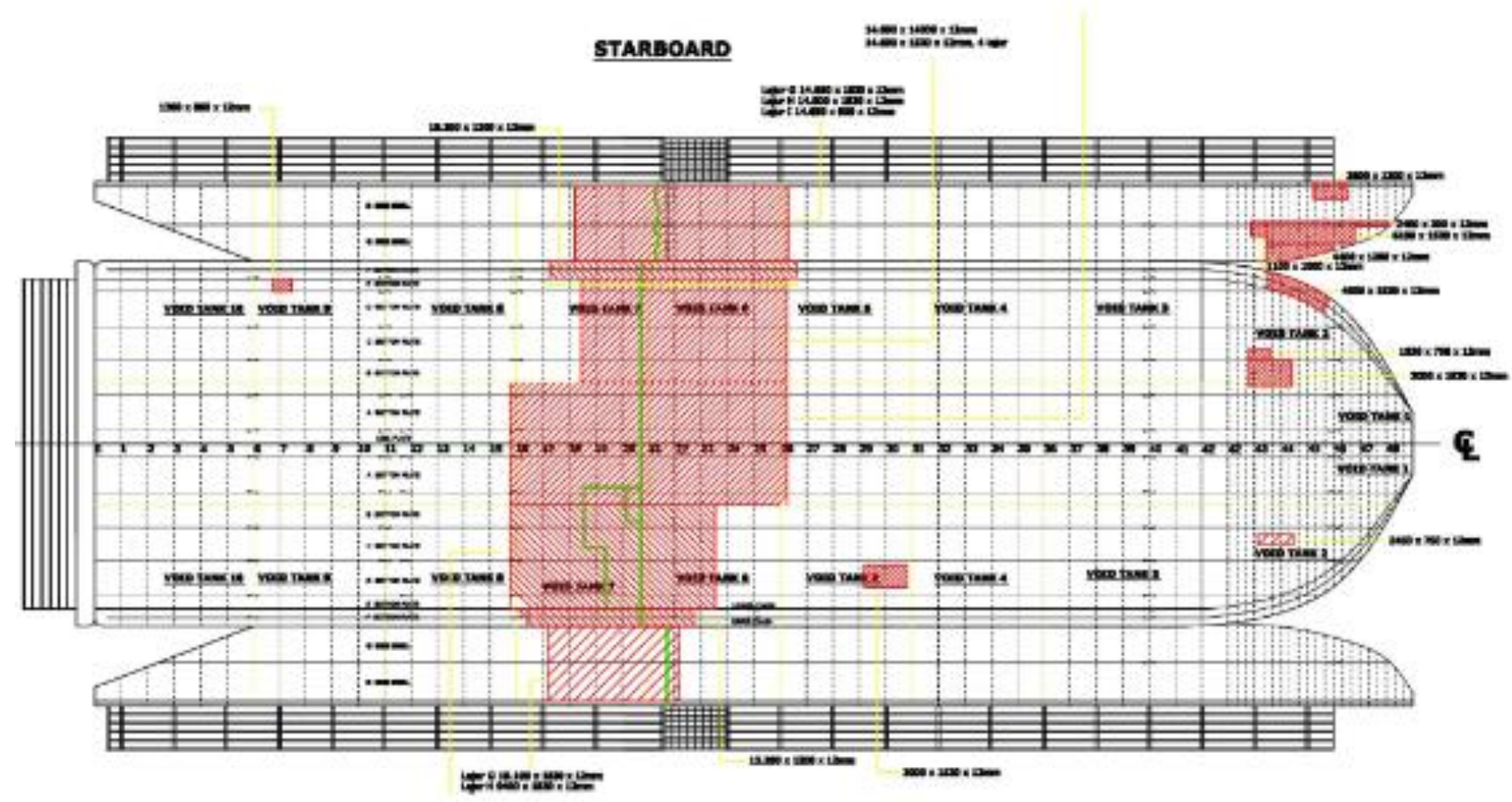

Gambar 1. Bukaan Kulit dengan Daerah Yang di Replating

Sesuai dengan sertifikat material yang ada di galangan, material pelat yang digunakan adalah baja A36 dengan yield strength pada kisaran 310
MPa sampai 377 MPa. Model midship section yang dibuat, diberikan kondisi batas berupa tumpuan jepit pada sekat depan dan belakang. 
Tipe elemen yang digunakan adalah triangular dengan 3 nodes. Formulasi elemen nya adalah constant strain triangle (interpolasi linear untuk displacement) [20]. Pemilihan meshing yang digunakan adalah uniform untuk size function yang digunakan pada bagian yang berbentuk sederhana seperti pelat; high smoothing untuk mendapatkan meshing yang tersusun rapi dan simetris satu sama lain; menggunakan metode dropped yaitu ketika perhitungan hanya pada ketiga node di elemen triangular. Penggunaan metode dropped bertujuan untuk mengurangi waktu simulasi dan kapasitas kerja komputer. Beban yang dimasukkan adalah muatan batu bara yang berbentuk limas dan prisma sesuai dengan jumlah gunungan bartu bara.

Dari data awal yang telah diambil, kemudian dilakukan pembuatan model dengan menggunakan program elemen hingga. Inti dari elemen hingga adalah membagi suatu benda yang akan dianalisa menjadi beberapa bagian dengan jumlah hingga (finite). Bagian-bagian ini yang menjadi acuan dalam hasil pemodelan karena banyak atau tidaknya jumlah elemen sangat mempengaruhi deformasi, tegangan, serta regangan yang akan terjadi pada struktur. Hal ini dikarenakan setiap bagian dari model mempunyai gaya, bentuk, dan beban yang berbeda pada tiap bidangnya, maka jika ukuran elemen yang dimasukkan ke dalam model sangat kecil, maka nilai tegangan yang dihasilkan akan besar karena setiap satu elemen yang terkumpul dalam satu layer bidang akan mewakili sepersekian millimeter dari elemen lainnya, hal ini juga tergantung pada parameter yang diberikan [21].

Data-data yang disimilarisasikan yaitu keseluruhan konstruksi profil kapal yang di reparasi mulai dari lebar kapal, tinggi kapal, panjang midship kapal, dimensi profil L, web frame dan sekat. Ketebalan midship section berbeda-beda disesuaikan dengan data Ultrasonic Test yaitu pada bagian deck memiliki ketebalan $7,2 \mathrm{~mm}$, side plate $8,2 \mathrm{~mm}$, bottom plate $9 \mathrm{~mm}$ dan bilge plate $11,5 \mathrm{~mm}$.

Gambar 2 menunjukkan pemodelan awal bagian midship section kapal yang disesuaikan dengan data konstruksi kapal pada software elemen hingga.

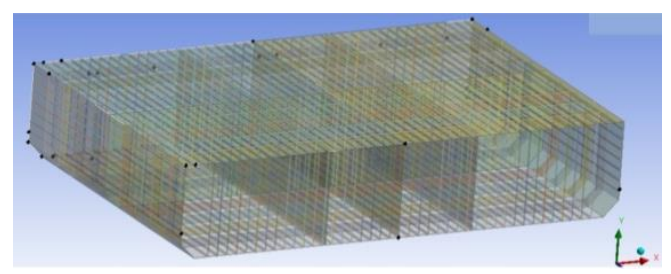

Gambar 2. Hasil Pemodelan midship section pada software elemen hingga
Untuk mengetahui tegangan yang terjadi pada tongkang NANIA, maka perlu dilakukan pemodelan pada bagian kapal yang di replating yang tujuannya adalah untuk mendapatkan besarnya pengaruh beban terhadap konstruksi geladak kapal.

Pembuatan model elemen hingga adalah pembuatan jaring-jaring elemen yang saling terhubung oleh nodal. Kemudian dilakukan pengecekan model dengan fitur joint untuk menyambungkan seluruh node yang ada. Jika model sudah terkoneksi secara benar, maka dilakukan pendefinisan material sesuai dengan sertifikat material di data, pemilihan jenis elemen yaitu tipe elemen triangular. Beban sesuai dengan perhitungan gunungan batu bara dimasukkan ke dalam model dan diberikan kondisi batas seperti kondisi jepit pada daerah bulkhead.

Semua hasil pengolahan data berupa gambar model, display hasil analisa, contour dianalisa untuk mengecek nilai tegangan, regangan dan deformasi. Dilakukan juga pengecekan terhadap area yang memiliki tegangan maksimum yang disesuaikan dengan area kapal yang direplatting di galangan.

Nilai deformasi dibandingkan dengan nilai deformasi di lapangan. Perhitungan safety factor dihitung dengan menggunakan BKI [22] dan sertifikat material.

\section{HASIL DAN PEMBAHASAN}

\subsection{Penentuan Tegangan}

Satu gunung batu bara direncanakan terletak pada bagian midship yang di replating. Gambar 3 dan Gambar 4 menunjukkan pembagian beban secara memanjang kapal dilihat dari tampak depan. Setiap irisan pada Gambar 3 memiliki jumlah tegangan yang berbeda. Jarak tiap pelat adalah 2,4 meter.

Pendekatan perhitungan pembebanan adalah dengan membagi satu gunungan batubara menjadi 12 beban yang nantinya akan dimasukkan sebagai input beban di elemen hingga. Gambar 4 menunjukkan pemodelan 3 dimensi dari satu gunungan baru bara. Dua gunung batu bara untuk pembagian 6 beban secara melintang dengan jarak 4,5 meter tiap beban divisualisasikan pada Gambar 5 dan Gambar 6. Gambar 5 menunjukkan pendekatan perhitungan pembebanan yaitu dengan membagi dua gunungan batubara menjadi 6 beban yang nantinya akan dimasukkan sebagai input beban di elemen hingga. Gambar 6 menunjukkan pemodelan 3 dimensi dari dua gunungan baru bara pada software elemen hingga. 
Sambungan las tidak dimodelkan secara khusus, hanya menyambungkan semua struktur yang dibuat dengan fasilitas joint material untuk menggabung semua struktur menjadi struktur yang solid.

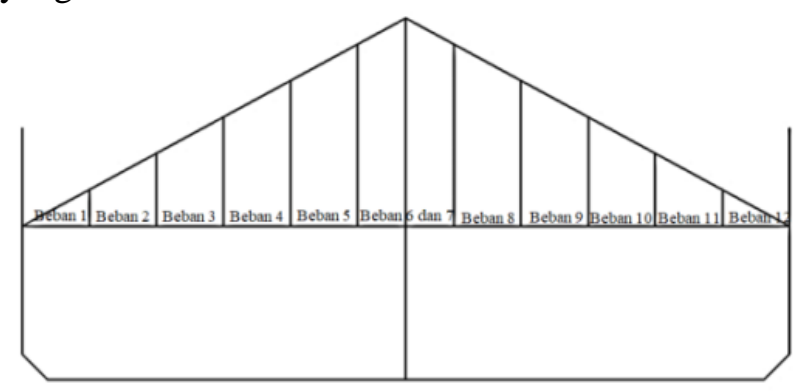

Gambar 3. Pemodelan 12 Beban untuk 1 gunung Batu Bara (tampak depan)

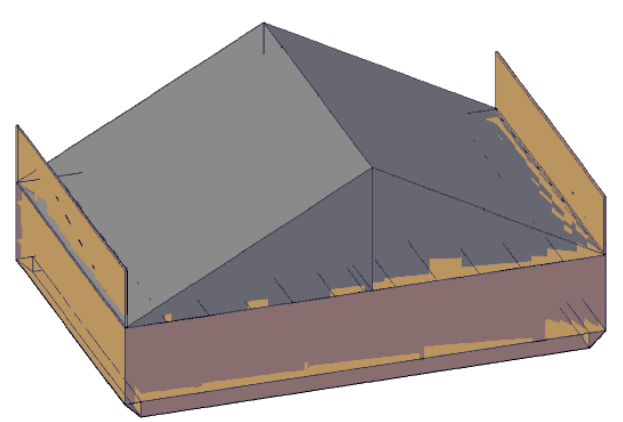

Gambar 4. Pemodelan 3D

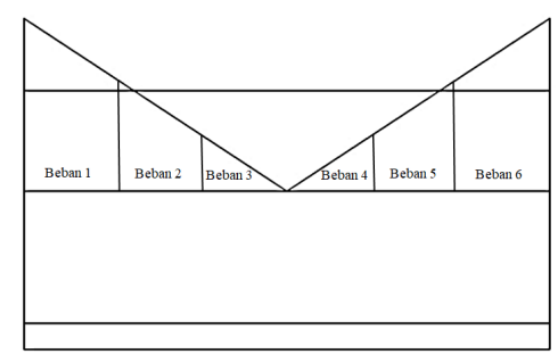

Gambar 5. Pemodelan 6 Beban untuk 2 gunung Batu Bara (tampak samping)

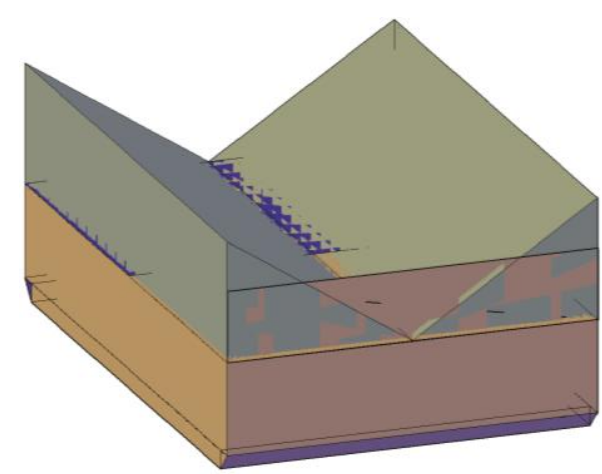

Gambar 6. Pemodelan 3D

\subsection{Hasil dan Titik Tegangan 1 Gunung Batubara}

Tabel 1. Elemen Dan Tegangan Maksimum Metode 1 Gunung

\begin{tabular}{|c|c|c|}
\hline Elemen & Stress (MPa) & $\% \Delta \sigma$ \\
\hline 0 & 0 & $0 \%$ \\
\hline 408.442 & 272,95 & $0 \%$ \\
\hline 678.308 & 354,91 & $2,31 \%$ \\
\hline 709.214 & 367,77 & $0,35 \%$ \\
\hline 847.541 & 384,35 & $0,43 \%$ \\
\hline 881.639 & 394,39 & $0,26 \%$ \\
\hline
\end{tabular}

Dari Tabel 1, dapat diketahui bahwa dari ke6 percobaan, hasil elemen dan tegangan tertinggi ada pada percobaan ke- 6 dengan ukuran meshing terkecil yaitu 0,069 meter. Dan dari persentase selisih tegangan yang terkecil ada pada percobaan ke-6 yaitu dengan angka $0,255 \%$. Semakin kecil selisih tegangan antara percobaan 1 hingga 6 maka hasil penelitian mendekati konvergen.

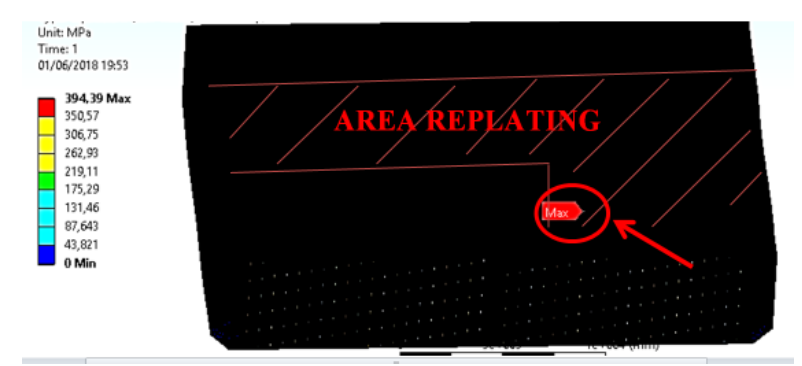

Gambar 7. Titik Tegangan Maksimum di Dalam Area Replating

Setelah mendapatkan nilai tegangan maksimum pada deck tongkang Nania, kemudian dilakukan pengecekan berdasarkan gambar reparasi dari galangan Meranti Nusa Bahari. Gambar 7 menunjukkan lokasi tegangan maksimum yang terletak didalam dalam area replating yaitu berada di pertemuan pelat antara sekat dan pelat deck dan terletak di frame ke-25 tepat di daerah midship.

\subsection{Hasil dan Titik Tegangan 2 Gunung Batubara}

Tabel 2. Elemen Dan Tegangan Maksimum Metode 2 Gunung

\begin{tabular}{ccc}
\hline Elemen & Stress (MPa) & $\boldsymbol{\%} \boldsymbol{\Delta} \boldsymbol{\sigma}$ \\
\hline 0 & 0 & $0 \%$ \\
408.441 & 223,95 & $0 \%$ \\
678.316 & 286,53 & $2,18 \%$ \\
709.200 & 335,29 & $1,45 \%$ \\
847.547 & 360,12 & $0,69 \%$ \\
881.635 & 369,97 & $0,27 \%$ \\
\hline
\end{tabular}

Dari Tabel 2 dapat diketahui bahwa dari ke-6 percobaan, hasil elemen dan tegangan tertinggi ada pada percobaan ke-6 dengan ukuran meshing terkecil yaitu 0,069 meter. Dan dari persentase 
selisih tegangan yang terkecil ada pada percobaan ke-6 yaitu dengan angka 0,266\%. Semakin kecil selisih tegangan antara percobaan 1 hingga 6 maka hasil penelitian mendekati konvergen.

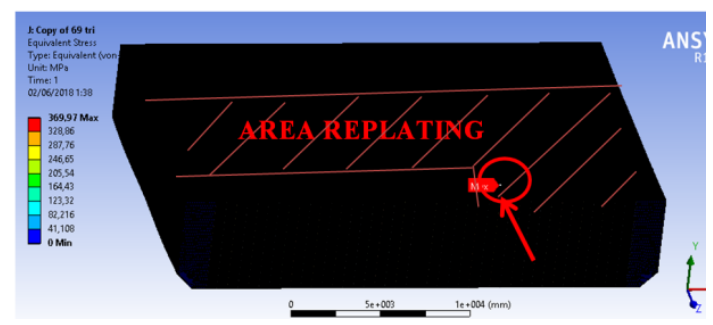

Gambar 8. Titik Tegangan Maksimum di Dalam Area Replating

Gambar 8 menunjukkan penyesuaian lokasi tegangan maksimum dari hasil penelitian dibandingkan daerah replating sesuai gambaran rencana replating $\mathrm{BG}$. Nania dari galangan Meranti Nusa Bahari. Tegangan maksimum terletak didalam area replating yaitu berada di pertemuan pelat antara sekat dan pelat deck dan terletak di frame ke-25 tepat di frame midship yang berarti temasuk bagian pelat yang dipotong.

Daerah yang memiliki nilai tegangan maksimum, berada pada daerah midship, dimana dari keseluruhan kapal, beban pada midship lebih besar dibandingkan lainnya. Hal ini dikarena shear force dan bending moment pada daerah midship memiliki nilai paling besar. Hal ini konsisten dengan yang terjadi di lapangan, yaitu daerah yang di replating dominan berada di daerah midship.

\subsection{Sensitifitas Meshing}

Sensitifitas meshing ialah proses konvergensi antara dua variabel yaitu jumlah elemen terhadap tegangan yang diinput ke dalam suatu grafik. Dari grafik tersebut dapat diketahui jumlah elemen dari yang terendah hingga paling tinggi begitu pun dengan tegangannya. Keuntungan dari meshing sensitivity ini yaitu dapat mempermudah proses penelitian dengan melihat jumlah elemen terbaik yang digunakan untuk struktur yang dianalisa [3].

Elemen dan tegangan tertinggi ada pada percobaan ke-6 dengan tegangan sebesar 394,39 MPa seperti pada Gambar 9.

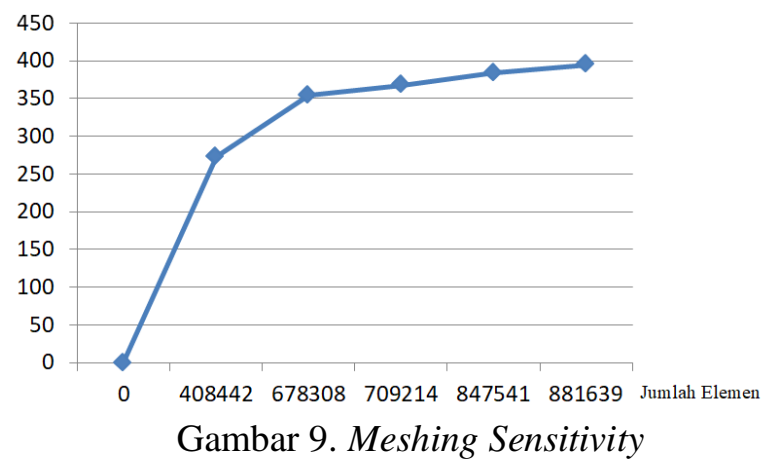

Grafik meshing sensitivity terbaik ada pada percobaan dengan metode pembebanan 1 gunung batu bara dengan titik tegangan maksimum terletak didalam area replating yaitu berada di titik temu las-lasan antara sekat dengan pelat deck yang terletak di frame ke-25 tepat di bagian tengah kapal. Untuk gambaran titik tegangan maksimum dan bentuk kontur tegangan dapat dilihat pada Gambar 10 dan 11.

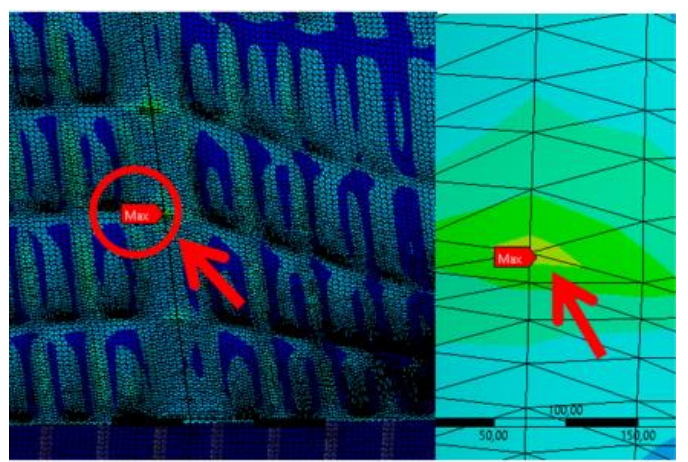

Gambar 10. Kontur tegangan Maksimum

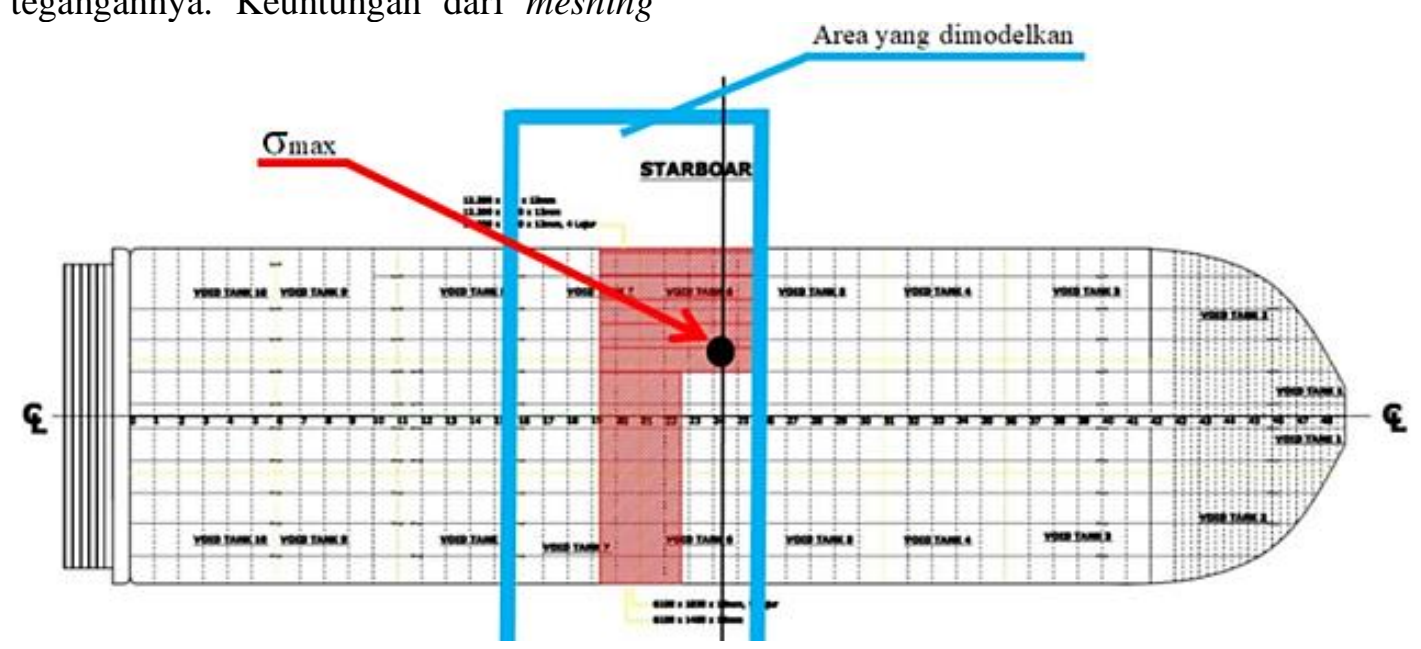

Gambar 11. Titik Tegangan Maksimum di Dalam Area Replating 
Tabel 3. Status Kedalaman Deformasi

\begin{tabular}{ccccc}
\hline $\begin{array}{c}\text { Metode } \\
\text { Pembebanan }\end{array}$ & $\begin{array}{c}\text { Jumlah } \\
\text { Elemen }\end{array}$ & $\begin{array}{c}\text { Kedalaman Deformasi } \\
(\mathbf{m m})\end{array}$ & $\begin{array}{c}\text { Batas Deformasi } \\
(\mathbf{m m})\end{array}$ & Status \\
\hline 1 gunung & 881.639 & 27,783 & 36 & Memenuhi \\
2 gunung & 881.635 & 28,765 & 36 & Memenuhi \\
\hline
\end{tabular}

Tabel 4. Yield Strength Material

\begin{tabular}{ccccccc}
\hline No & $\begin{array}{c}\text { Metode } \\
\text { Pembebanan } \\
\text { Batu Bara }\end{array}$ & $\begin{array}{c}\text { Tipe } \\
\text { Elemen }\end{array}$ & $\begin{array}{c}\text { Ultimate } \\
\text { Strength } \\
(\mathbf{M P a})\end{array}$ & $\begin{array}{c}\text { Yield } \\
\text { Strength } \\
(\mathbf{M P a})\end{array}$ & $\sigma(\mathbf{M P a})$ & $\begin{array}{c}\text { Status Tegangan } \\
\text { dibandingkan } \sigma_{\mathbf{u}}\end{array}$ \\
\hline 1 & 1 gunung & Triangular & 514 & 377 & 394,39 & aman \\
2 & 2 gunung & Triangular & 514 & 377 & 369,97 & aman \\
\hline
\end{tabular}

Tabel 5. Perhitungan safety factor menurut sertifikat material kapal Nania

\begin{tabular}{cccccccc}
\hline $\begin{array}{c}\text { Tipe } \\
\text { Elemen }\end{array}$ & $\begin{array}{c}\text { Metode } \\
\text { Pembebanan }\end{array}$ & Elemen & $\begin{array}{c}\text { Max } \\
\text { Stress } \\
(\mathbf{M P a})\end{array}$ & $\begin{array}{c}\text { Teg. } \\
\text { Yield } \\
(\mathbf{M P a})\end{array}$ & $\begin{array}{c}\text { Tegangan } \\
\text { Ultimate } \\
(\mathbf{M p a})\end{array}$ & $\begin{array}{c}\text { SF } \\
\text { dgn } \\
\boldsymbol{\sigma}_{\mathbf{u}}\end{array}$ & Ket. \\
\hline Triangular & 1 gunung & 881.639 & 394,39 & 377 & 514 & 1,303 & Memenuhi \\
Triangular & 2 gunung & 881.635 & 369,97 & 377 & 514 & 1,389 & Memenuhi \\
\hline
\end{tabular}

\subsection{Pengecekan Kedalaman Deformasi}

Pada Tabel 3, kedua percobaan memiliki nilai yang kurang dari angka batas deformasi (36 $\mathrm{mm})$. Dapat dilihat pada Gambar 12 bahwa titik merah menunjukkan kedalaman deformasi maksimum dengan luas $0,36 \mathrm{~m}^{2}$.

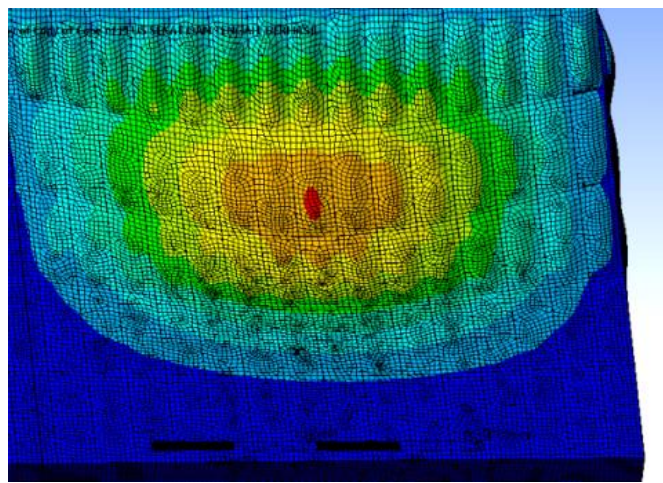

Gambar 12. Titik Deformasi Maksimum

\subsection{Pengecekan Batas Yield Strength Material}

Pada Tabel 4, hasil tegangan yang paling rendah ada pada percobaan ke-2 dengan nilai tegangan 369,97 $\mathrm{MPa}$. Acuan dari besar atau tidaknya tegangan maksimum yang dihasilkan yaitu dari besarnya yield strength yang terdapat pada sertifikat material Barge Nania yaitu 377 $\mathrm{MPa}$.

\subsection{Pengecekan Standar Keamanan Material (Safety Factor)}

Kriteria pelat yang digunakan adalah pelat baja A36 dan perhitungan safety factor mengacu pada sertifikat material berdasarkan BKI [22].
Material yang digunakan adalah baja kekuatan tinggi $\mathrm{ReH} 377$, dan didapatkan tegangan yield sebesar $377 \mathrm{MPa}$ dan tegangan ultimate $514 \mathrm{Mpa}$ sesuai yang tertera pada Tabel 5 .

Perhitungan safety factor dilakukan dengan membandingkan hasil tegangan simulasi dengan tegangan ultimate sertifikat material dan didapatkan nilai SF rata-rata 1,346 yang berarti nilai tersebut diatas standar keamanan material yaitu 1. Jika ditinjau dari luasan deformasi dan lokasi tegangan maksimum yang berada di area replating, maka adanya kesesuaian antara hasil analisa terhadap kondisi kapal pada saat di reparasi.

\section{KESIMPULAN}

Berdasarkan dari hasil pengujian yang telah dilakukan sebelumnya maka dapat dihasilkan kesimpulan bahwa: 1) Hasil tegangan maksimum untuk metode pembebanan 1 dan 2 gunung ialah 394,39 $\mathrm{MPa}$ dan 369,97 $\mathrm{MPa}$; 2) Kedalaman deformasi dari kedua tipe pembebanan yaitu $27,783 \mathrm{~mm}$ dan $28,765 \mathrm{~mm}$ yang masih dibawah toleransi deformasi maksimum (36 mm) dan 3 ) Nilai safety factor berdasarkan tegangan ultimate sertifikat material kapal Nania ialah 1,303 dan 1,389. Nilai rata-rata safety factor dari keseluruhan percobaan yaitu 1,346, diatas angka standar $\mathrm{SF}=1$. Dalam hal ini, kapal tongkang Nania mengembalikan kekuatan struktur dengan melakukan replating pada bagian-bagian yang mengalami deformasi dan pada pelat yang sudah menipis. 


\section{UCAPAN TERIMA KASIH}

Terima kasih kepada Institut Teknologi Kalimantan atas bantuannya membantu penulis dalam menyelesaikan penelitian ini.

\section{DAFTAR PUSTAKA}

[1] J.M.EkmannP.H.Le, "Coal Storage and Transportation," in Encyclopedia of Energy, Elsevier, 2004, pp. 551-580.

[2] T. Smith, Belajar Mengenal Kapal konstruksi-tongkang, Indonesia: online, 2015.

[3] AMeinkenH.-JSchlüter, "Collapse behaviour of a push-barge," Marine Structures, vol. 15, no. 2, pp. 193-209, 2002.

[4] F. Papalangi, I. P. Mulyatno and P. Manik, "Studi Perancangan Tongkang Pengangkut Limbah Batubara di PLTU Tanjung Jati B Jepara," Jurnal Teknik Perkapalan, vol. 3, pp. 222-229, 2015.

[5] L. Adnyani, "Analisa Kekuatan Ultimate Hull Girder FPSO Dengan Pendekatan Metode Elemen Hingga Nonlinear," Jurusan Teknik Kelautan, ITS, Surabaya, 2014.

[6] P. T. P.A. Lakshmynarayanana, "Application of CFD and FEA coupling to predict dynamic behaviour," Marine Structures, no. 65, pp. 308-325, 2019.

[7] U. m. Silalahi, H. Yudo and U. Budiarto, "Analisa Pengaruh Variasi Sarat Tongkang Terhadap Ekonomis Pemasukan (Income) Pengangkutan Muatan dan Oeprasional Tug Boat," Jurnal Teknik Perkapalan, vol. 4, pp. 132-140, 2016.

[8] N. Samson, E. Ogbonnaya and K. Ejabefio, "Stability Analysis for the Design of 5000tonnes Offshore Work Barge," International Journal of Engineering and Technology, vol. 3, no. 9, pp. 849-857, 2013.

[9] S. Jatmiko and Saptadi, "Analisa Kekuatan Deck Tongkang Muatan Tiang Pancang 750 DWT dengan Software Berbasis Metode Elemen Hingga," $K A P A L$, vol. 8, no. 1, pp. 29-34, 2011.

[10] A. Rohmani, "Analisa Kekuatan Modifikasi Konstruksi Geladak Utama Kapal LCT VIP JAYA 893 GT Dengan Metode Elemen Hingga," Program Studi S1 Teknik Perkapalan, Undip, Semarang, 2015.

[11] W. Yunanto, "Analisa Kontruksi Car Deck Kapal Ropax 5000GT Dengan Metode Elemen Hingga," Program Studi S1 Teknik Perkapalan, Undip, Semarang, 2014.
[12] B. Arswendo, "Analisa Kekuatan Deck Pada Ponton Batu Bara Prawiramas Puri Prima II 1036 DWT Dengan Software Berbasis Metode Elemen Hingga," Program Studi S1 Teknik Perkapalan, Undip, Semarang, 2011.

[13] I. Pujo, "Strength Analysys Of Container Deck Construction MV. Sinar Demak Efect Of Charges Container Using Finite Element Method," rogram Studi S1 Teknik Perkapalan, Undip, Semarang, 2012.

[14] E. AdnanKefal, "Displacement andstressmonitoringofachemicaltankerbased," Ocean Engineering, no. 112, pp. 33-46, 2016.

[15] W. M. P. J. b. B. Sukumarana, "Efficient finite element techniques for limit analysis of suction caissons under lateral loads," Computers and Geotechnics, no. 24, pp. 89107, 1999.

[16] M. T. D. G. R. C. R. C. P. Daniel J. Getter, "Determination of hurricane-induced barge impact loads on floodwalls using dynamic finite element analysis," Engineering Structures, no. 104, pp. 95-106, 2015.

[17] D. R. C. Gary R. Consolazio, "Nonlinear analysis of barge crush behavior and its relationship to impact resistant bridge design," Computers and Structures, no. 81, pp. 547-557, 2003.

[18] A. P. R. J. Erasmo Carrera, "Refined beam finite elements for static and dynamic analysis of hull structures," Computers and Structures, no. 167, pp. 37-49, 2016.

[19] V. A. A. F. Y. Ahmet H. Ertas, "Finite Element Simulation of a Mercantile Vessel Shipboard Under Working Conditions," in 24th DAAAM International Symposium on Intelligent Manufacturing and Automation, 2013, Viena, 2014.

[20] U. o. N. Mexico, "2D Triangular Elements," University of New Mexico, Albuquerque, 2010.

[21] C. Desai, Dasar-dasar Metode Elemen Hingga, Jakarta: Erlangga, 1998.

[22] B. K. Indonesia, Rules for Classification and Construction of Sea Going Steel Ship Volume II : Rules for Hull Edition 2014, Jakarta : Biro Klasifikasi Indonesia, 2014. 